\title{
Transition to Circular Economy in the Fertilizer Sector-Analysis of Recommended Directions and End-Users' Perception of Waste-Based Products in Poland
}

\author{
Marzena Smol (D)
}

check for updates

Citation: Smol, M. Transition to Circular Economy in the Fertilizer Sector-Analysis of Recommended Directions and End-Users' Perception of Waste-Based Products in Poland. Energies 2021, 14, 4312. https:// doi.org/10.3390/en14144312

Academic Editor: Attilio Converti

Received: 11 June 2021

Accepted: 15 July 2021

Published: 17 July 2021

Publisher's Note: MDPI stays neutral with regard to jurisdictional claims in published maps and institutional affiliations.

Copyright: (C) 2021 by the author. Licensee MDPI, Basel, Switzerland. This article is an open access article distributed under the terms and conditions of the Creative Commons Attribution (CC BY) license (https:// creativecommons.org/licenses/by/ $4.0 /)$.
Mineral and Energy Economy Research Institute, Polish Academy of Sciences, 31-261 Ceacow, Poland; smol@meeri.pl

\begin{abstract}
Circular economy (CE) is an economic model, in which raw materials remain in circulation as long as possible and the generation of waste is minimized. In the fertilizer sector, waste rich in nutrients should be directed to agriculture purposes. This paper presents an analysis of recommended directions for the use of nutrient-rich waste in fertilizer sector and an evaluation of possible interest in this kind of fertilizer by a selected group of end-users (nurseries). The scope of research includes the state-of-the-art analysis on circular aspects and recommended directions in the CE implementation in the fertilizer sector (with focus on sewage-based waste), and survey analysis on the potential interest of nurseries in the use of waste-based fertilizers in Poland. There are more and more recommendations for the use of waste for agriculture purposes at European and national levels. The waste-based products have to meet certain requirements in order to put such products on the marker. Nurserymen are interested in contributing to the process of transformation towards the CE model in Poland; however, they are not fully convinced due to a lack of experience in the use of waste-based products and a lack of social acceptance and health risk in this regard. Further actions to build the social acceptance of waste-based fertilizers, and the education of end-users themselves in their application is required.
\end{abstract}

Keywords: circular economy; nurseries; fertilizer; waste; waste management

\section{Introduction}

Nowadays, providing a satisfactory amount of food is one challenge of great priority [1]. It results from a constantly growing world population and potential threats of the 21st century (such as closing a country's borders and restrictions on import-export, occurring in the case of a pandemic) [2]. The advances in science, medicine, and technology [3] in the previous decades have a great impact on human population development. According to the statistics provided by the World Population Review [4], a number of people living on Earth in 2021 reached a level higher than 7.8 billion. This number has grown by 1.3 billion since 2000, and based on predictions provided by the United Nations Department of Economic and Social Affairs (2019) it continue to rise-at least by $10 \%$ - until 2030. It also inflicts a necessity to provide sustainable access to basic resources that are essential for sustaining life, such as food, fresh water and pure air [5].

The aspects described above have contributed to changes in the general characteristics of modern food production. Due to rapidly growing socio-economic demands, both crops and animal farming started to be highly dependent on the use of agrochemicals, such as fertilizers and pesticides [6]. According to an international statistical report, the annual mineral fertilizer consumption in the European Union (EU) has risen by about 1.54 million $\mathrm{Mg}$ since 2009 [7]. It is a fact that as well as the direct influence on the environment, food quality and human and animal health, fertilizer and pesticides also impact the global economy. Currently, a large fraction of fertilizers and pesticide products are based on limited fossil resources [8]. This statement applies mainly to products that consist of 
phosphates, produced from phosphorite rocks [9]. The primary reserves of this type of resources are located in Morocco, China or Russia [10]. From the European perspective, most of the listed countries are considered as a political risk. Therefore, it is important to take actions aimed to identify, evaluate and implement a sustainable strategy that can provide safety to the European fertilizers market, and thus also provide access to raw materials for plant production in the Member States. Such an approach is included in the newest strategy of the EU's growth-the European Green Deal (EGD). An important part is a circular economy (CE) which is an economic model focused on resource efficiency [11] that includes the perspective of both raw materials management and waste management [12]. In the case of the fertilizer sector, the transformation to the CE model has great potential for successful implementation. First, the more sustainable use of fertilizers from primary sources and fertilization methods should be promoted and implemented, which concern the main users of fertilizers, who are farmers, but also nurserymen. Secondly, many waste streams (including food waste, sewage sludge, manure, and others) can be successfully used as substitutes for commercial fertilizers [13]. These two approaches may significantly accelerate the transformation towards the $\mathrm{CE}$, as so far, the European Commission (EC) has introduced many recommendations and strategic documents in this regard [14]. The current paper presents an inventory of the circular aspects and the recommended directions in the implementation of the CE assumptions in the fertilizer sector in the EU and Poland. Moreover, the paper includes an analysis of determinants influencing the possibility of using waste-based fertilizers in a selected group of stakeholders in the fertilizer sectornurserymen. Usually, only farmers are indicated as the potential users of waste-based products, while nurserymen are overlooked in research on behaviour, awareness, and trends in the use of waste-based fertilizers. Therefore, this research focuses on these potential users of waste-based products in food production. The implementation of the CE principles and convincing the future end-users of waste-based fertilizers could help secure access to raw materials needed for agricultural production (including phosphorus), and thus increase the safety of society.

\section{Materials and Methods}

The research was divided into three individual steps. The first step includes the state-of-the-art analysis. The second step focuses on the identification of determinants influencing the possibility of using fertilizers from waste in a selected group of stakeholders. The third step provides a discussion of the obtained results and comparison with other authors. The methods used in these three steps (desk research and survey analysis) are described below.

\subsection{Desk Research}

In the first step, a detailed analysis of the state of the art was conducted. The main objective of this step of research was to identify circular aspects and recommended directions in the implementation of the CE assumptions in the fertilizer sector in the EU and Poland. The state of the art analysis was conducted with the use of the desk research method [15]. It included a comprehensive analysis of available source data related to the following areas: waste management, the fertilizer sector and circular economy (at European and national levels). The circular aspects and the recommended directions were searched in the European documents related to mentioned areas of research. A special focus was dedicated to the possibility of producing mineral fertilizers based on waste generated in the water and wastewater sector, as sewage sludge and sewage sludge ash. Most of the availed sources (directives, regulations, communications, reports, working documents) were published online (free of charge) on an official website of the EU (ec.europa.eu, assessed 14 April 2021) and the EUR-Lex-online database with EU Law (eur-lex.europa.eu, assessed 14 April 2021), and the Polish Internet System of Legal Acts-ISAP (isap.sejm.gov.pl). This step also included a revision of available reviewed articles published in scientific databases such as Elsevier Scopus, Springer Nature, Google Scholar and Multidisciplinary Digital 
Publishing Institute (MDPI). The selection of literature was made based on a keywords, which determine the scope of the original database obtained and influence the results of the entire review. The keywords used in the current study were identified and consulted with experts in the given field. The following keywords were used: "circular economy", "CE", "waste", "waste management", "fertilizer", "fertilization", "nutrients recovery". As a consequence of increasing popularity and importance of issues such as the CE and waste management in recent years, the initial analysis gave several hundred papers and documents. A large part of them were rejected because they did not take into account the issues related to the fertilizer sector. Then, data extraction, which aimed at the identification of the most significant information from each item, was conducted. The results of the state-of-the-art analysis are presented in Sections 3.1-3.3.

\subsection{Survey Method}

In the second step of the research, determinants influencing the possibility of using fertilizers from waste in the selected group were indicated. In this study, representatives of nurseries were selected as the group of respondents due to there being a lack of available sources presenting an analysis of this group of stakeholders (most of the research focusses on famers' preferences and consumers' acceptance). In order to identify their preferences in terms of the use of fertilizers from waste, a diagnostic survey was used. It focused on collecting statistical data and facts about a given phenomenon (use of waste-based fertilizers) and its possible development. The questionnaire survey was chosen as the main method of empirical study. The survey design included a development of questions in accordance with specific sub-areas of the research framework. The specific sub-areas included questions about determinants of the usage of waste-based fertilizers and future trends, and preferences related to the usage of waste-based fertilizers. The questionnaire survey consisted of 10 closed-questions with single-choice and multiple-choice answers. Research areas of the questions are presented in Figure 1.

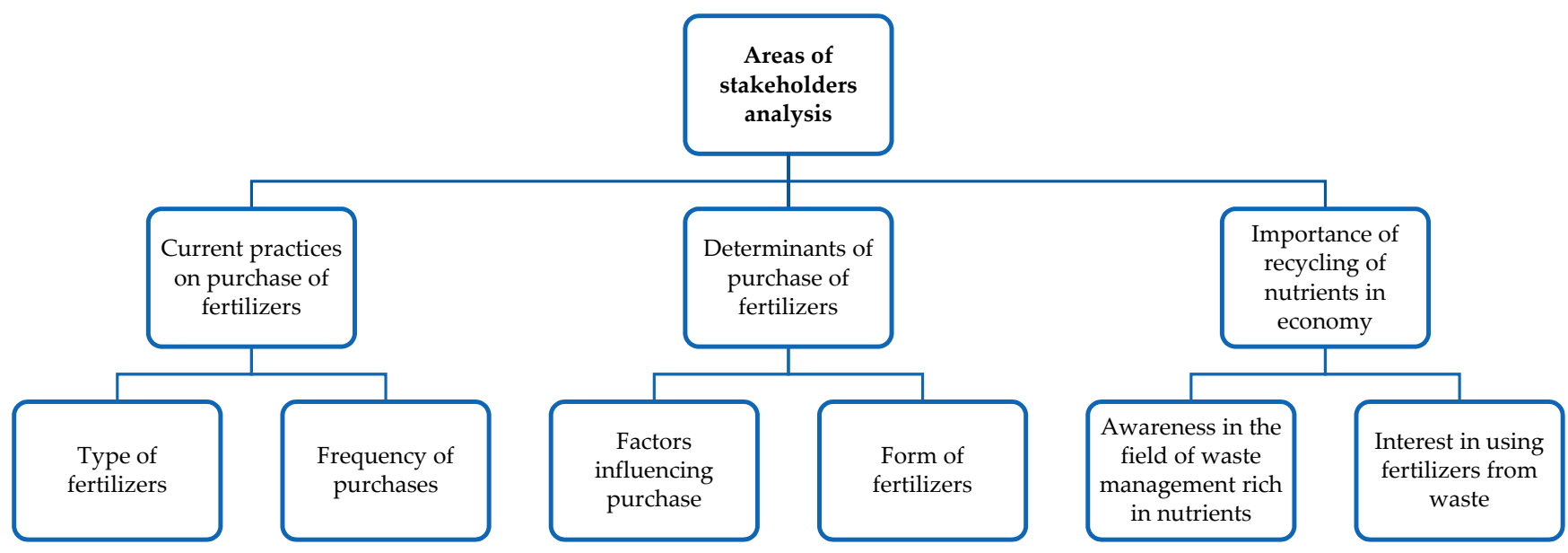

Figure 1. Research areas of stakeholder analysis.

The research was conducted with the use of the Computer Assisted Telephone Interview (CATI). The sample size (n) was 32 representatives of nurseries in Poland, who apply various fertilizers to crops (fruit bushes and vegetables). The representatives of nurseries who deal with ornamental shrubs and flowers were not analysed in the study. Research was conducted from August to September 2019. Participation in the research was on a voluntary basis. The study complied with all restrictions regarding the protection of personal data as indicated in General Data Protection Regulation (GDPR), and sensitive data were not collected by the researcher [16].

The questions were formulated in a way to identify the cultivated area and regions where they run a nursery. The survey method was used as a supplementary source of data 
(to the literature review) on possible drivers to use waste fertilizers. The results obtained in this step of research are presented in Section 3.3 of this paper.

\section{Results and Discussion}

\subsection{Waste-Based Fertilizers in the European Strategic Documents}

In 2014, the first official document on the CE implementation was presented by the EC, entitled "Towards a circular economy: A zero waste programme for Europe", related to the CE [12]. It clearly indicated the importance of sustainable waste management as the key area of the CE implementation in the EU. The tackling of specific waste challenges related to an uncontrolled loss of resources or environmental impacts was announced. The special area of interest was dedicated to the recycling of critical raw materials (CRMs), including phosphorus $(\mathrm{P})$, which is vital resource for food production and a key component in fertilizers. The $\mathrm{P}$ raw materials included on the CRMs list are phosphate rock and white $\mathrm{P}$ [17-19]. The importance of $\mathrm{P}$ raw materials deserves particular attention, as their production worldwide is concentrated in few non-European countries, such as in Morocco, China, the United States, Kazakhstan, and Vietnam, and from the EU's perspective, most of the listed countries are considered as a political risk. The structure of the global producers and main EU sourcing countries of phosphorus and phosphate rock is presented in Figure 2. The import reliance for phosphate rock is $84 \%$ and phosphorus $100 \%$, while the End of Life Recycling Input Rate (percentage of overall demand that can be satisfied through secondary raw materials) for phosphate rock is $17 \%$ and phosphorus $0 \%$. At the European level, $\mathrm{P}$ resources have low substitutability and low recycling rates [20], which is a consequence of inappropriate P management, causing P losses at every stage of its lifecycle [21]. As $P$ raw materials are a base of fertilizer production [22], the EC underlined the necessity to develop a policy framework on $\mathrm{P}$ to enhance its recycling, foster innovation, improve internal market conditions and make its sustainable use mainstream in EU legislation on fertilizers, water, food and waste [12,23].

In 2015, a second official document on CE was published, entitled "Closing the loopAn EU action plan for the Circular Economy" [24]. It showed the first CE Action Plan for the EU, in which the legislative proposals on waste showed long-term targets to reduce landfilling waste, including nutrient-rich waste [25], and to increase preparation for the recycling of key waste streams, such as municipal waste. As one of the main barriers in the usage of waste-based fertilizers in the EU, differences across the Member States in rules as well as quality and environmental standards were indicated. It was assumed that indicated targets and planned activities should lead the European countries to gradually converge on best practice levels and accelerate the requisite investment in sustainable and circular waste management. The EC also stated that the revision of the European regulations on fertilizers shall be conducted in the coming years. An important statement of the EC was also to list the recycled nutrients (used as fertilizers) as a distinct category of secondary raw materials, which require the development of their quality standards [24].

The first implementing act of the CE Action Plan was "Proposal laying down rules on the making available on the market of CE marked fertilizing products", published in 2016 [26]. The innovative fertilizing products, including waste-based fertilizers, were clearly indicated as products which are in line with the CE model [27]. However, they have difficulties accessing the internal market as a consequence of the diversity of national rules and standards on fertilizers and fertilization. The inclusion of the waste-based fertilizers in the Fertilizer Regulation was challenging because of the relatively variable composition and characteristics of such materials. Therefore, the ex-post evaluations, stakeholder consultations and impact assessments were conducted before the final revision of the Fertilizer Regulation was published in 2019 [28]. 
Main global producers of phosphate rock

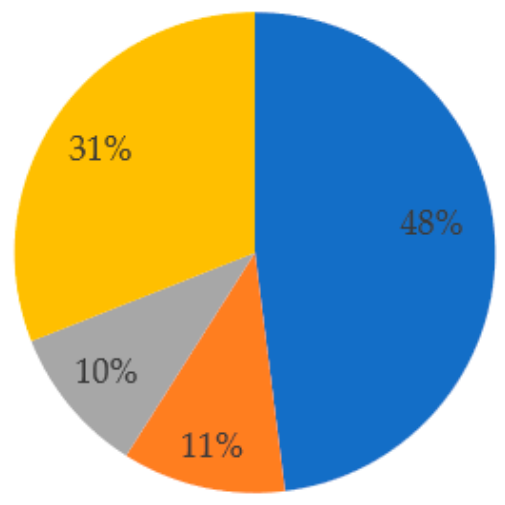

China घorocco $\quad$ United States $\quad$ Others

Main global producers of phosphorus

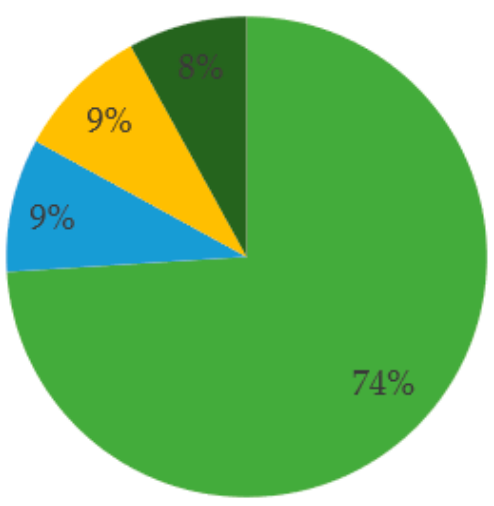

Main EU sourcing countries of phosphate rock

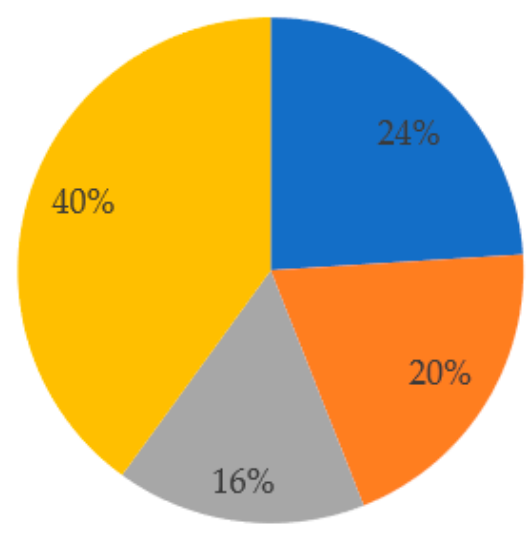

- Morocco $\quad$ Russia $n$ Finland $n$ Others

\section{Main EU sourcing countries of phosphorus}

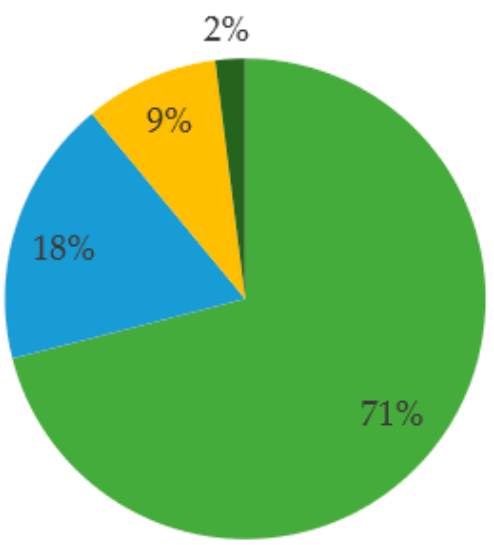

Figure 2. Structure of global producers and main EU sourcing countries of phosphorus and phosphate rock, own analysis based on [19].

The new Fertilizer Regulation pointed towards a need to increase the usage of recycled and organic materials for fertilizing purposes. The harmonised conditions for the distribution and use of waste-based fertilizers made from recycled or organic materials available on the entire internal market were established. One of the most important proposed actions was to increase the efforts for the promotion of recycled nutrients as the driving force for the more resource-efficient general use of nutrients, thus accelerating the transformation process toward the CE model in the EU in 2019 [28]. Moreover, sustainable and circular nutrient-rich waste could reduce the European dependency on fertilizer raw materials (such as P) from external countries [29]. The scope of the harmonisation therefore was extended to include recycled and organic materials. The increasing demand for waste-based fertilizers such as struvite [30], biochar [31,32], manure [33] and ash-based products [13,34] was also announced. It was already proven that the usage of these waste as substitute of fertilizers could contribute to reducing the usage of synthetic fertilizers in cropland, and through this to mitigate environmental and human health threats [33,35]. Moreover, the usage of these materials in fertilizer production may improve not only the recovery of nutrients from waste, but also increase crop yields, while abating climate change [36]. However, the usage of any waste material for economic purposes requires adjustments to 
legal regulations. In the new Fertilizer Regulation, certain requirements were indicated as necessary for the use of waste materials in the recovery and treatment processes, as well as for fertilizing products. The key challenge was to ensure that the use of waste-based fertilizing products did not lead to overall adverse environmental or human health impacts. The EC also underlined that in the previous years, a promising technical progress was observed in the field of the recovery of nutrients from different waste streams such as $\mathrm{P}$ recovery from wastewater, sewage sludge or sewage sludge ash, and fertilizing product production from animal by-products, such as biochar [28]. The most important aspect of the current regulation was clearly indicated in the criteria in accordance with which material that constitutes waste, as defined in Directive 2008/98/EC [37], can cease to be waste if it is contained in a compliant European fertilizing product. In this case, it is required to conduct the recovery operation before the material ceases to be waste. In addition, this material shall be considered to comply with the conditions provided in that Directive, and therefore to have ceased to be waste when the EU declaration of conformity was accepted [28].

In the end of 2019, the EC presented the new growth strategy for the EU, which is the European Green Deal (EGD) [38]. The main target of the EGD is to convert Europe into first climate neutral continent by 2050. To achieve this goal, all European actions and policies should contribute to an effective and fair transition. The critical aspects for the fertilizer sector in this green transition are plans to reduce waste significantly and the reduction of the environmental impact of the fertilizer use in agriculture [39]. The proper management of food waste, allowing the use of nutrients, is also promising [40]. The EC plans to identify measures, including legislative, needed to reduce the environmental impact of fertilizers based on a stakeholder dialogue. The challenges of sustainable food systems were identified in the newest Farm to Fork Strategy [41], the so-called heart of the EGD. The necessity for intensive activities on building the circular bio-based economy is a largely untapped potential for farmers and their cooperatives. There is a recommendation to reduce nutrient losses by at least $50 \%$, while ensuring that there is no deterioration in soil fertility. This could reduce the use of fertilizers by at least $20 \%$ by 2030 . The way to achieve it is to implement and enforce the relevant environmental and climate legislation, by inventorying with Member States the nutrient load reductions needed to achieve these goals, applying balanced fertilization and sustainable nutrient management. An important issue in the Farm to Fork Strategy is also the more sustainable management of nutrients such as nitrogen and phosphorus throughout their lifecycles. The EC announced the development of an Integrated Nutrient Management Action Plan (INMAP) to address nutrient pollution at the source and increase the sustainability of the livestock sector. The proposed considerations of this plan were indicated by the European Sustainable Phosphorus Platform (ESPP) [42], which stated that this plan should:

- Address nutrients across all existing areas of the European policy (including environment, water, industrial emissions, air, raw materials, waste, CE, agriculture, food, diet, animal feed, fertilizers, climate change and others);

- Include all nutrients (including nitrogen, phosphorus and other nutrients and micronutrients and soil organic carbon);

- Integrate the current European policies and implementation structures (including agricultural funding and rural development, water basin management organisations, and others) to be realistically implemented by entrepreneurs and by local and regional authorities.

The ESPP points out that it is strongly recommended to propose and implement the specific tools to address the relatively low market price of nutrients and the lack of a monetarised price on nutrient environmental impacts. This makes the recovery economically unprofitable (small-scale processing, contaminants and safety requirements, decentralised logistics) and often, waste-based fertilizers are more costly than fertilizers produced from primary sources. This is due to the lack of monetised environmental or social benefits such as pollution abatement, soil preservation, primary resource savings, local job creation in the European regulatory and fiscal framework. 
The Farm to Fork Strategy also underlines improvement in the application of precise fertilization techniques and sustainable agricultural practices. It is extremely important in hotspot areas of intensive livestock farming and of the recycling of organic waste into renewable fertilizers [41].

Another part of the EGD [38] is the Common Agricultural Policy (CAP) which combines social, economic and environmental approaches on the path towards the sustainable system of agriculture in the whole EU [43]. The agricultural activity is sustained by good environmental conditions, allowing farmers to use natural resources [44] to produce the agricultural products while earning a living. The food produced by farmers serves the livelihood of the whole society. The CAP can help the green transition and strengthen the efforts of farmers, agri-food businesses, foresters, and rural communities to tackle climate change and protect the environment. The key part of the CAP budget (up to 40\%) is dedicated to the climate-relevant activities [45].

In 2020, the second CE Action Plan was established [46]. The special part of this plan is dedicated to food, waste and nutrients management. Next to the development of the INMAP, the EC also plans to consider reviewing directives on wastewater treatment and sewage sludge and the assessment of natural means of nutrient removal, for example, by algae.

Summing up, the transformation towards CE in various sectors of the economy (including the fertilizer sector) is an irreversible process. This is confirmed by a number of recommendations and legal regulations systematically introduced at the European level. Further works are expected on technologies on nutrients recovery and methods of waste management for fertilization purposes, as well as works in the field of sustainable fertilization. This is especially important for the CRMs such as phosphorus, which is a key raw material in agricultural production, but also contributes to eutrophication. To achieve the ambitious goals of the Green Deal, further activities in this area (at the level of changes in the legalization and implementation of new solutions) will be carried out within the framework of the second CE Action Plan. The EC also emphasizes that the implementation of the $C E$ requires systematic change and innovation. Changes in the practices of the main stakeholder groups, i.e., fertilizer producers (both from primary and secondary sources), fertilizer organizations, fertilizer users-from small (nurserymen) to large-scale (farmers) — as well as consumers themselves, are strongly welcome.

\subsection{Waste-Based Fertilizers in the National Strategic Documents-Poland Case Study}

The Polish fertilizer industry is one of the most developed sectors of the domestic chemical industry. It covers the production of ammonia, ammonium nitrate, urea, ammonium and calcium phosphates, mineral acids and the production of final products, which are solid and liquid mineral fertilizers [47]. From the CE perspective, the fertilizer industry has great possibilities to manage waste generated in other sectors of the economy, such as the water and wastewater sector.

On the national level, the most important legal regulations on fertilizer production (nomenclature, chemical composition, including the content of nutrients and permissible content of impurities, physical form, bioavailability, and other requirements) are the Act on Fertilizers and Fertilization [48] and Regulation of the Minister of Agriculture and Rural Development [49].

The Act on Fertilizers and Fertilization [48] regulates (i) conditions and procedures for placing fertilizers and plant conditioners on the market in Poland, (ii) tasks and the competence of organs and organizational units in the field of fertilizers and plant conditioners, (iii) the application of fertilizers and plant conditioners in agriculture, (iv) preventing threats to human and animal health and the environment, which may arise as a result of transport, storage and use of fertilizers and plant conditioners and (v) agrochemical services for agriculture. According to this act, there is a possibility to use different fertilizers in agriculture, such as mineral, organic or mineral-organic fertilizers, manure, slurry and guano. The admissible types of contaminants in fertilizers and plant conditioners 
and their values as well as minimum quality requirements to be met by fertilizers are indicated in the Regulation of the Minister of Agriculture and Rural Development [49]. The permissible value of pollutants in organic and organic-mineral fertilizers, as well as organic and organic-mineral agents supporting the cultivation of plants may not exceed, in the case of chromium (Cr) $-100 \mathrm{mg} / \mathrm{kg}$, cadmium (Cd) $-5 \mathrm{mg} / \mathrm{kg}$, nickel (Ni) $-60 \mathrm{mg} / \mathrm{kg}$, lead $(\mathrm{Pb})-140 \mathrm{mg} / \mathrm{kg}$, mercury $(\mathrm{Hg})-2 \mathrm{mg} / \mathrm{kg}$, while in mineral fertilizers and agents supporting cultivation of plants of mineral origin: arsenic (As) $-50 \mathrm{mg} / \mathrm{kg}$, cadmium$50 \mathrm{mg} / \mathrm{kg}$, lead-140 mg/kg, mercury $-2 \mathrm{mg} / \mathrm{kg}$. Depending on the intended use of crops (horticulture, forestry, vegetable crops, field crops, grasslands) different entities are entitled to conduct agricultural and biological research or to issue opinions on fertilizers and plant conditioners.

The transition to the CE model in the fertilizer sector is supported by the implementation of the CE assumptions in the main Polish regulation on waste management-the National Waste Management Plan 2022 [50]. The recommendation for the use of waste as a source of nutrients in fertilizers is indicated for municipal waste (including food waste and other biodegradable waste) and municipal sewage sludge. It is strongly recommended to promote bio-waste treatment technologies, as a result of which, full-value and environmentally friendly material used for fertilizing or reclamation is obtained. The dominant direction of biodegradable waste recovery (as waste from the agri-food sector) is the production of organic fertilizers and components for the production of compost. There is also a strong emphasis on phosphorus recovery from water-based waste, as sewage sludge and sewage sludge ash. Moreover, the rational management of ashes by its landfilling in a manner allowing one to recover phosphorus is indicated. In the management of biodegradable waste (other than municipal waste), the line of action has been adopted consisting in the development of technical infrastructure, reuse and recovery (including recovery fertilizer raw materials) of this waste.

One of the most important strategic documents on the management of nutrient-rich waste is the "Strategy for treatment of municipal sewage sludge in 2019-2022" [51]. The dynamic development of sewage networks and municipal wastewater treatment plants (WWTPs) has led to the formation of large amounts of municipal sewage sludge. The development of the network water and sewage systems are accompanied by an increase in the communal capacity of WWTPs and the application of the in-depth removal of nutrients there. In these plants, the amount of municipal sewage sludge, as a potential source of secondary raw materials in the fertilizer sector, systematically increases. The use of municipal sewage sludge is highly recommended as a substrate for the production of organic fertilizers or plant conditioners. Products made from municipal sewage sludge can be placed on the market after obtaining a permit of the minister responsible for agriculture. To obtain a permit, the specific tests of physicochemical, chemical and biological properties carried out by an accredited laboratory and opinions of relevant research institutes on meeting the quality requirements and suitability for use must be provided. There is also an issue related to P-rich sewage sludge ash. The fertilizer granules obtained from ashes from biomass combustion and municipal sludge sewage have not been used for agricultural purposes in Poland so far, so it can be concluded that it is a substance "unknown in fertilization". The recommended direction is to produce mineral ash-based fertilizers in the chemical or thermochemical treatment (extraction) instead of granulation. There is a high possibility of this area being effective, and more and more units are working in this area [52].

The use of biowaste as source of raw materials is also included in the Polish "Roadmap Transformation towards a circular economy" [53]. This strategic document shows the most important areas of CE implementation in Poland. The special interest is dedicated to bioeconomy. It should be underlined that most EU countries place great emphasis on the bioeconomy [54]. The possibility of transformation toward CE in Poland in the fertilizer sector is linked to the energy sector. Biomass as a source of phosphorus [55] or potassium [56] is currently one of the most popular renewable energy sources in the country. 
Biomass is also indicated a possible source for the production of organic fertilizers [57]. Moreover, the rational use of mineral and organic fertilizers is recommended as one of the ways to protect the soil environment and prevent eutrophication. In the coming years, the development of norms and standards for particular categories of products made from biomass is planned. The standardisation activities should contribute to consumer and user confidence in products made from biomass, including compost and other organic fertilizers [53].

In 2021, the Polish New Industrial Policy (PNIP) is being prepared. The PNIP is a programme targeted at industrial sectors, which will complement the Productivity Strategy with its sectoral approach. As part of the PNIP, problems and barriers of individual industries will be defined and specific solutions using legislative and institutional instruments will be proposed. One of the key areas of this document will be strategies and tools for the Green Deal implementation, indicated as an accelerator of the transformation towards the CE model in country. Facing the depletion of non-renewable resources (such as phosphorus), rising prices and growing dependence of Poland from their supplies from abroad, which creates risks for the further economic development of the country and challenges in the context of environmental protection, it is necessary to accelerate the transformation towards the $\mathrm{CE}$ as an indispensable element of the creation of a low-carbon, resourceefficient, innovative and competitive Polish economy. In this context, the strengthening of raw material recovery activities in the fertilizer sector will be continued [58].

To sum up, strategic documents have been systematically introduced in Poland to strengthen the implementation of the CE. One of the industries with high potential is the fertilizer sector, and it correlates with other industries and entities, such as the water and sewage sector and the energy sector (biomass producers). Further works on the implementation of the CE model is continued in the country, including the promotion of the use of fertilizers from waste and the participation of various stakeholder groups in the transformation process towards the CE.

\subsection{Stakeholder Analysis Regarding the Use of Waste-Based Fertilizers}

According to the report of the Main Inspectorate of Plant Health and Seed Inspection, the area of eligible nursery crops in 2019 was 774.98 ha in Poland. The largest area among qualified nursery crops was occupied by fruit tree nurseries. The production of fruit trees was carried out on almost 343 ha and was carried out by 156 nurserymen. The types of nursery material in 2019 in Poland are presented in Table 1. In 2019, strawberry plantations were run by a total of 20 producers on just over 126.81 ha. In turn, mother plantations of strawberry seedlings (elite) covered 11.30 ha (9 producers). Approximately 25 ha were occupied by raspberry seedlings, which were produced by a total of 11 nurserymen. The mother plantation of raspberry seedlings (elite) covered $20.45 \mathrm{ha}$, and their cultivation was carried out in five nurseries. In 2019, the production of berry bushes was carried out on an area of approximately 23.63 ha in 23 nursery farms. Plantations of bushes intended for the production of seedlings took up approximately 9.53 ha (in 24 nurseries), and elite plantations of berry bushes intended for the production of seedlings-approximately 2.44 ha (in six nurseries). Nurseries of berry bushes intended for reproductive plantations were run only on approximately 0.48 hectares in four farms. A total of 38 nurseries with an area of 22.40 ha managed to obtain scions from mother orchards. This year, the area of mother orchards for obtaining seeds was about 11.94 ha (18 producers), and the area of fruit tree nurseries intended for spore and seed orchards was 0.30 ha (two producers). 
Table 1. Area of eligible nursery crops in 2019 by type of nursery material and number of producers in Poland [59].

\begin{tabular}{|c|c|c|c|}
\hline No. & Type of Nursery Material & Area (ha) & $\begin{array}{l}\text { Number of } \\
\text { Producers }\end{array}$ \\
\hline 1. & Prebasic material & 0.22 & 1 \\
\hline 2. & Elite plantation of berry bushes intended for the production of seedlings & 2.44 & 6 \\
\hline 3. & Plantation of bushes intended for the production of seedlings & 9.53 & 24 \\
\hline 4. & Mother plantation of vegetative rootstocks (elite) & 5.80 & 1 \\
\hline 5. & Mother plantation of raspberry seedlings (elite) & 20.45 & 5 \\
\hline 6. & Mother plantation of strawberry seedlings (elite) & 11.30 & 9 \\
\hline 7. & Plantation of generative rootstocks & 10.13 & 36 \\
\hline 8. & Plantation of vegetative rootstocks & 161.55 & 203 \\
\hline 9. & Plantation of raspberry seedlings & 24.99 & 11 \\
\hline 10. & Plantation of strawberry seedlings & 126.81 & 20 \\
\hline 11. & Mother orchard for seed collection & 11.94 & 18 \\
\hline 12. & Mother orchard for obtaining scions & 22.40 & 38 \\
\hline 13. & Nursery of fruit trees & 343.01 & 156 \\
\hline 14. & Nursery of fruit trees intended for pest and seed orchards & 0.30 & 2 \\
\hline 15. & The nursery of berry bushes & 23.63 & 23 \\
\hline \multirow[t]{2}{*}{16.} & A nursery of berry bushes intended for reproductive plantations & 0.48 & 4 \\
\hline & Total: & 774.98 & - \\
\hline
\end{tabular}

The results of the perspectives of representatives of nurseries regarding the use of waste-based fertilizers are presented in Figures 3-8. In total, out of 323 producers of eligible nursery crops, 32 representatives of the Polish nursery production industry participated in the research. Those representatives who took part in the survey came from selected voivodeships in the country (seven from Lublin Voivodeship, six from Masovian Voivodeship, six from Podkarpackie Voivodeship, four from Lesser Poland Voivodeship, three from Silesian Voivodeship, three from Kuyavian-Pomeranian Voivodeship, three from Łódź Voivodeship). These voivodships have the largest number of eligible nursery crops producers, compared to other regions in Poland.

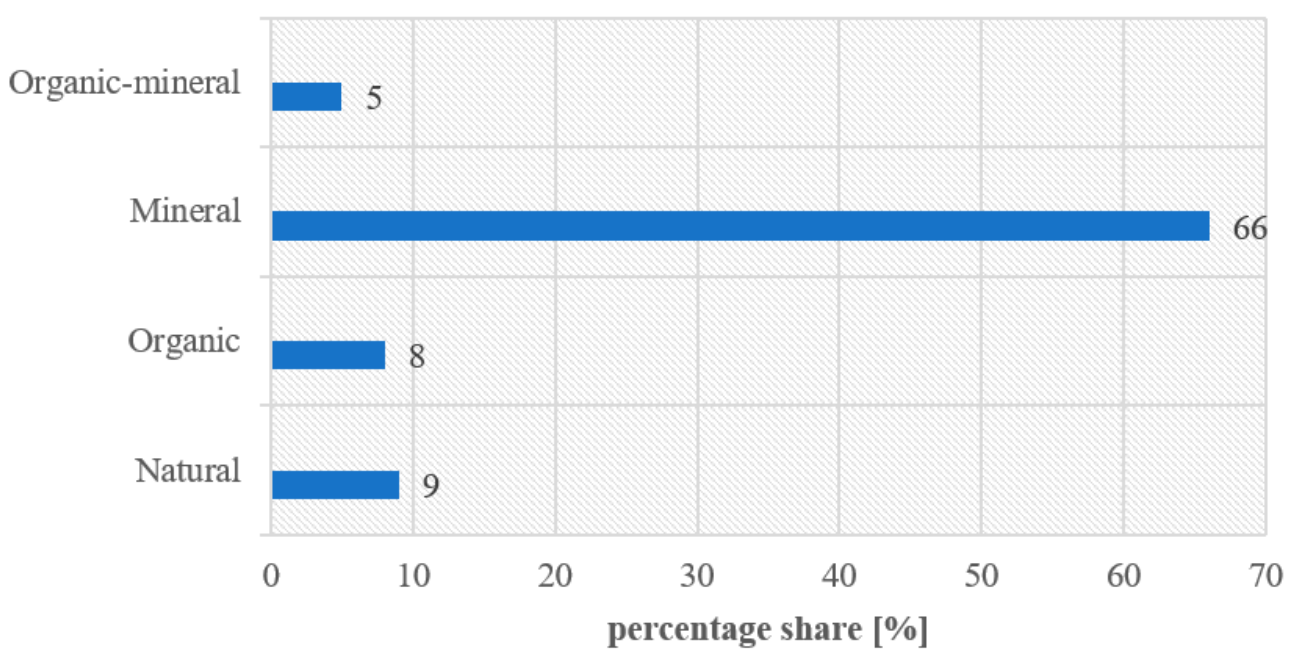

Figure 3. The types of fertilizer purchased. 


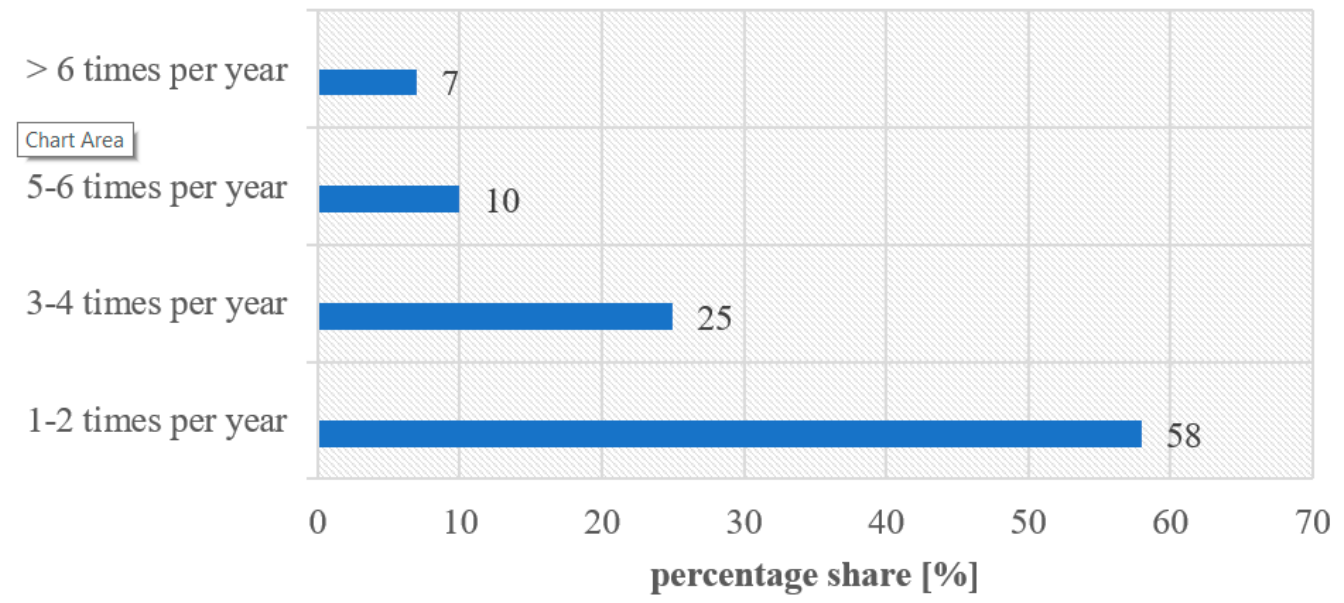

Figure 4. Frequency of purchase of fertilizers.

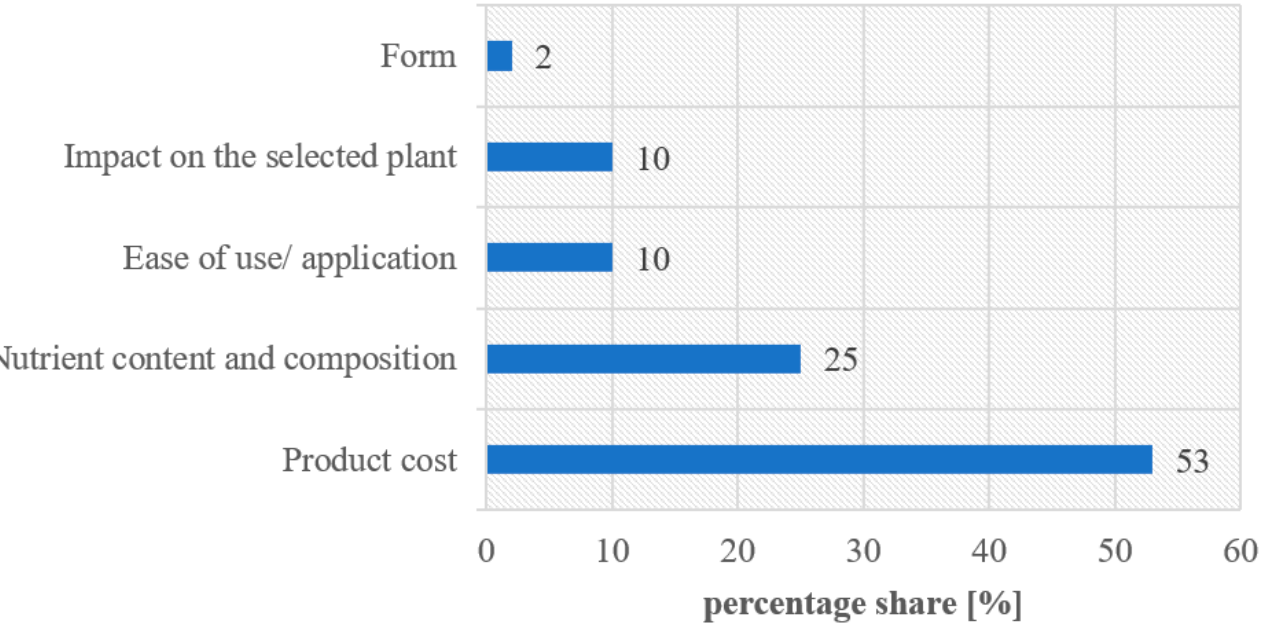

Figure 5. Factors influencing the purchase of fertilizers.

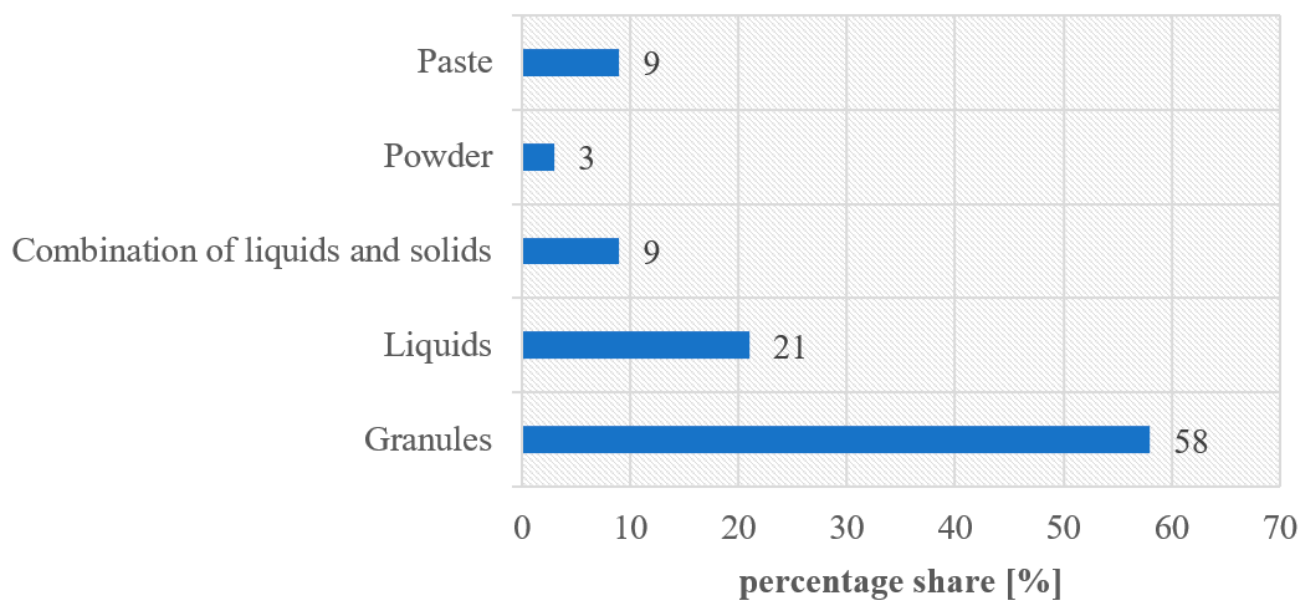

Figure 6. Preferred form of fertilizers. 


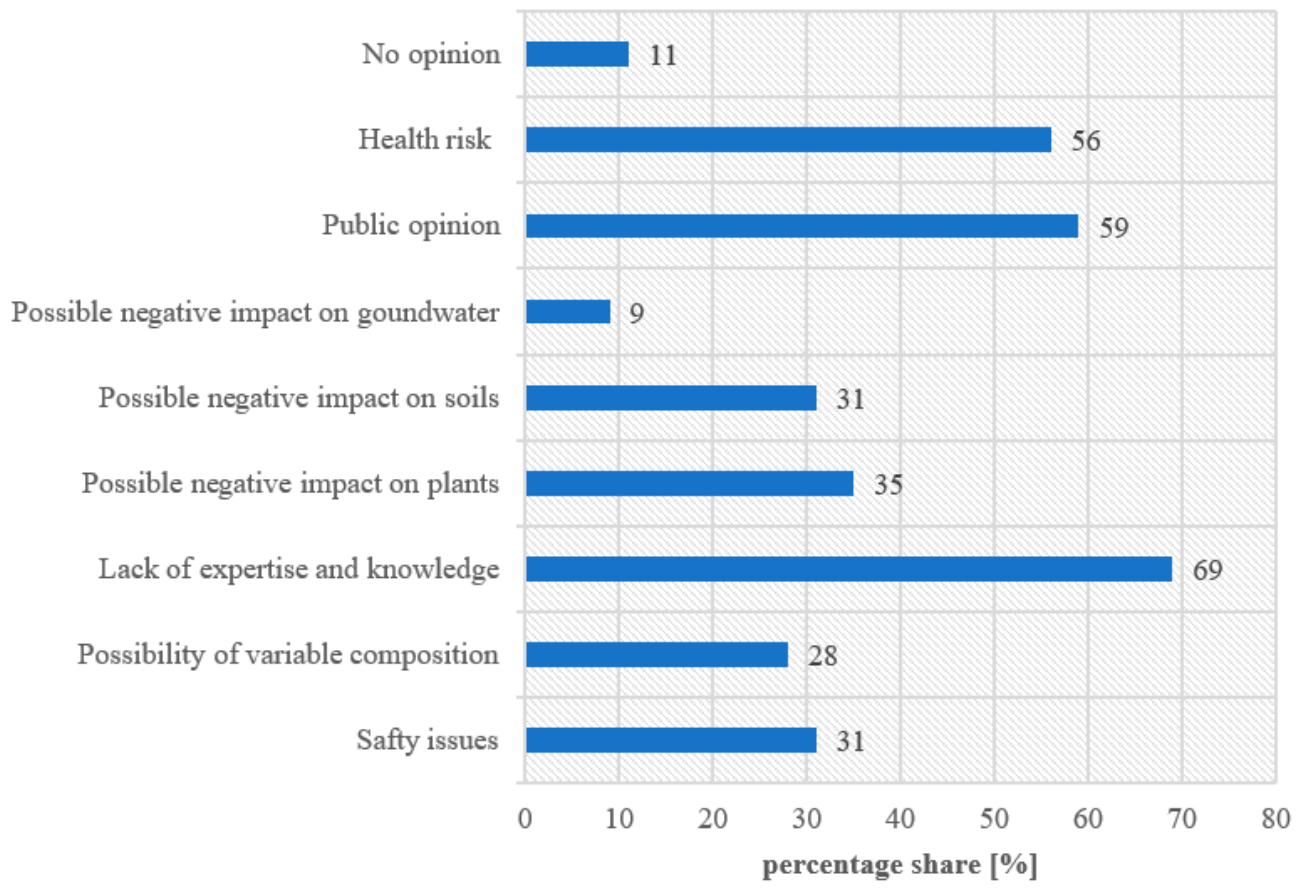

Figure 7. Concerns about using fertilizers from waste (multiple choice).

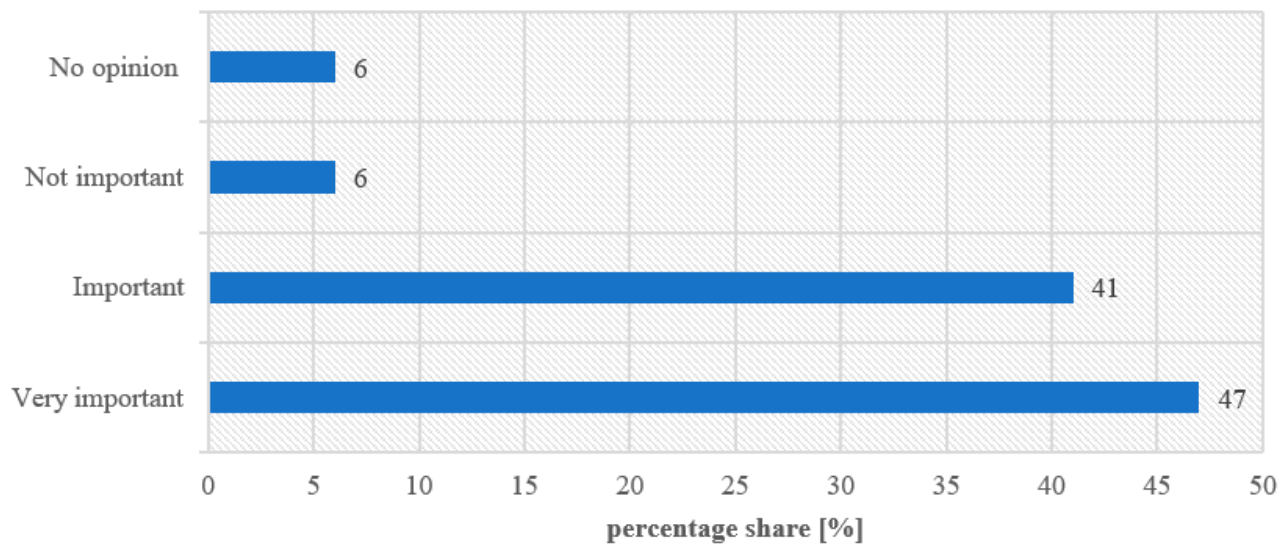

Figure 8. Importance of sustainable circular management of nutrient-rich waste.

\subsubsection{Current Practices on Purchase of Fertilizers}

In the first stage of the survey research, the respondents were asked whether they use fertilizers in their plantations and what kind of fertilizers they buy. The respondents mainly buy multi-component fertilizers (78\%), while a definite minority use single-component fertilizers (18\%), and only $4 \%$ declared that they do not use any fertilizers at all. The next questions in this section were related to the type of fertilizers purchased and the frequency of purchases. The research findings on respondents' behaviour with regard to the 'current practices on purchase of fertilizers' are presented in Figures 3 and 4.

Most of the respondents declared that they buy the mineral fertilizers $(66 \%)$. A comparable number of respondents buy natural (9\%) and organic fertilizers (8\%). Only $5 \%$ of respondents indicated the purchase of mineral-organic fertilizers. In the case of the frequency of these purchases, the analysed stakeholder group makes a purchase one to two times a year. Such a response was declared by $58 \%$ of the respondents. In total, $25 \%$ of respondents purchase fertilizers three to four times a year, $10 \%$ five to six times, and $7 \%$ more than six times per year. 


\subsubsection{Determinants of Purchase of Fertilizer}

Currently, the most important factor which determines the purchase of the fertilizers is the cost of product. For more than $50 \%$ of respondents, it was main criteria when buying the fertilizers. For $25 \%$ of the analysed representatives of nurseries, the content of the selected nutrients and the composition of fertilizers is the most important factor. A comparable number of respondents draw attention to the ease of the use of a given fertilizer and its application, and the effect of the fertilizer on the plant (i.e., $10 \%$ for both criteria). Factors influencing the purchase of fertilizers are presented in Figure 5. The analysis of the determinates of the usage of waste-based fertilizers among farmers also showed that the profitability of applying these materials compared to chemical fertilizers is the most important factor for purchase/usage of these products [60]. Tur-Cardona et al. (2018) indicated that waste-based fertilizer, similar to commercial chemical fertilizers, could be sold at around $65 \%$ of the price of mineral fertilizer. Other important determinants are the presence of organic carbon, the hygienization of the product and the fast release of nutrients.

Most of the analysed respondents (58\%) prefer the granulated form of the fertilizers (Figure 5). The liquid form is mainly chosen by about $21 \%$ of the analysed nurserymen, while the liquid-solid combination is preferred by $9 \%$-similar to paste. For only $3 \%$, powdered fertilizers are the preferred form.

\subsubsection{Importance of Recycling of Nutrients in Economy}

In this stage of survey research, the respondents were asked about their possible interest in buying the waste-based fertilizers. The interviewer presented a list of different groups of waste-based fertilizers, which have similar properties to commercial fertilizers purchased by the respondents. All respondents knew that it is possible to use fertilizer from waste in agricultural production; however, only $60 \%$ declared that they would be potentially interested in using this type of fertilizers. About $40 \%$ of the respondents considered such a new offer not very attractive on the market. The lack of conviction about the use of fertilizers from waste resulted from several factors that are presented in Figure 7. The most frequently indicated barrier in the use of waste fertilizers was the lack of knowledge and experience in this area (69\%). Important limitations are also issues related to health safety $(56 \%)$ and general public opinion (59\%) regarding the use of waste, especially such as manure or urine in fertilization in nurseries. For selected respondents, the negative impacts on solid (31\%) and plants (35\%) were also possible limitations. The variable composition of such products also limits the potential interest in this type of fertilizer $(28 \%)$. The safety of use is also an important issue for $31 \%$ of respondents. The possible negative impact on groundwater was indicated as the limitation for only $9 \%$ of representatives of nurseries. Some of the respondents $(11 \%)$ did not express an unambiguous opinion in this regard.

It should be underlined that the representatives of the nursery production clearly indicated that the most important feature of this kind of fertilizer could be the ability to increase humus in the soil (68\%). Moreover, the added value of the waste-based fertilizers are that they are easy to use (38\%) and possible to use in the form of granules $(71 \%)$.

In this part of research, the respondents were also asked about their opinion on waste management. For almost $90 \%$ of them, the issues related to the sustainable and circular management of nutrient-rich waste are important and very important (Figure 8).

The involvement of various stakeholder groups in building a 'recycling society' is indicated by the EC as a key element in building of the CE model in Europe [12]. Therefore, in the transition to the $\mathrm{CE}$ model, increasing public awareness was declared as one of the major driving forces $[61,62]$. The previous evaluation of factors affecting the condition of the natural environment in rural areas showed that full acceptance of local communities with regard to balancing social, economic and environmental aspects play a fundamental role in the evolution of the Polish agriculture towards sustainability [63]. Due to the fact that the CE applies to the more rational management of raw materials and more sustainable management of waste, the use of nutrients contained in different waste streams 
to process fertilizers is a strongly recommended direction. In the fertilizer industry, the most promising stakeholders are producers and users of fertilizers (such as farmers and nurserymen). Therefore, the dissemination of knowledge and sharing experience is highly recommended [64], next to the increase in awareness and education in the use of fertilizers from waste. It could support the transformation process towards the CE at regional, national and international levels [65].

It was already proven that an incentive to use fertilizers from waste and to promote this solution is the membership of the stakeholders in the agriculture cooperatives, subsidies on organic fertilizers. There, they can obtain required education materials about the wastebased products, collaborate and share knowledge, as well as participate in education events. These organisations can also provide opinions and recommendations to update extension policies of organic fertilizers [66]. The awareness campaign is proposed to bridge whatever information gap there might be in the use of waste-based fertilizer in order to strengthen stakeholders' (farmers') resolve [67].

The fertilizer application is one of the major activities in the nursery. To increase the use of fertilizers from waste in this sector is a very promising element in the process of transformation towards the CE. Materials and types of fertilizers for nursery plants vary in different companies due to varying management practices and soil types used.

The representatives of nurseries have not been analysed so far in terms of their potential interest in the use of fertilizers from waste and determinants affecting the choosing (purchase) of such products. There are more and more papers presenting attitudes, behaviours and detriments in the usage of waste-based fertilizers by farmers. However, none of these works analyses the possibility of using this type of fertilizers by nurserymen, which is quite surprising, as they are also an important group in the food supply chain (as initial producers of fruit and vegetables).

The key attributes determining the acceptance of farmers in selected European and non-European countries to the alternative waste-based fertilizers were analysed in a few works [63,67-69]. In research of Tur-Cardona et al. (2018) the analysed farmers from the different countries showed common preferences for concentrated products that have certainty in the nitrogen content and at a lower price than chemical fertilizer. In some cases, the farmers are willing to pay a higher price for the waste-based fertilizer, but only if the product is certified [68]. The identified barriers in the use of waste-based products are also the unpleasant odour for neighbours and difficulty in planning [69]. Moreover, one of the most important limitations of the usage of waste-based fertilizer by farmers is the control of quality in these products and uncertainty in the nutrient content [70]. In many countries, particularly in Europe, very strict rules for the nursery production of certified fruit and vegetable plants are provided [71]. Therefore, farmers and nurserymen are concerned about contamination of their products. In the case of using fertilizers from waste for food production (such as vegetables and fruits), all standards regarding the limits of contamination in these fertilizers must be met [28]. It is obvious that the retail and food industry have quality requirements for food products, but also and consumers and citizens have an impact on the development potential of markets for waste-based products $[60,72]$. The potential users of the waste-based organic fertilizers also indicated some concerns related to this solution, as they are afraid to lose income [66] or experience an increase in their own costs if they chose organic fertilization instead of chemical fertilizers [73]. An important aspect is also the creation of a new or adapting the currently functioning business model so that the use of waste for economic purposes would be profitable for the user [74].

The coronavirus pandemic created a promising perspective of changing the stakeholders behaviours and attitudes to the use of waste as sources of secondary raw materials. Social distancing, which was a consequence of the pandemic, improved the performance of food purchases and changed food waste management practices [75]. However, staying at home made people produce more household waste, which is a nasty incident [76]. The improvements on the separate collection of various groups of waste may contribute to 
their better disposal—directing them to the recovery process [77], including the direction of nutrient-rich waste to fertilizer purposes [78-80]. For many years, fertilizer technologies have increasingly used renewable resources (as primary sources of $\mathrm{P}$ ) [22] and the majority of fertilizer products are still based on mineral deposits and fossil fuels [81], and now, in the transformation process toward the $\mathrm{CE}$, the innovation of and increase in the usage of waste-based fertilizers are required $[82,83]$. The production of waste-based fertilizers on a commercial scale has great prospects for further development [67] and it will be continued to be implemented in the following years.

\section{Conclusions}

The European initiatives on the circular economy and the Green Deal strongly underline the importance of the sustainable and circular management of raw materials and waste. Currently, raw materials that are used in agricultural production, and are at the same time indicated as critical (as phosphorus), deserve special attention. In the case of a shortage of critical raw materials necessary for food production and potential restrictions on the flow of raw materials and imports from non-European countries, it may have a very negative impact on food production and quality of life in the EU. Therefore, the EC aims to use the nutrients contained in waste (wastewater, sewage sludge, sewage sludge ash, manure, biochar and others) as much as possible, so that they can be recycled as waste-based fertilizers. Similar recommendations are included in national regulations, including Polish regulations concerning waste management, especially rich in nutrients (e.g., municipal sewage sludge and sewage sludge ash). Among the potential users of such products are farmers, but also nurserymen, who are usually overlooked in research on behavior, awareness and trends in the use of waste-based fertilizers. The current study showed that nurserymen are potentially interested in actively participating in the transformation toward the $\mathrm{CE}$ in the fertilizer sector by using waste-based fertilizer. However, they indicated some concerns, such as lack of knowledge and experience in the use of such products. Therefore, further efforts to raise awareness of the importance of the sustainable and circular use of waste fertilizers and increase in competences among end-users of waste-based products are necessary.

Author Contributions: Conceptualization, methodology, investigation, writing-original draft preparation, writing - review and editing, visualization M.S. All authors have read and agreed to the published version of the manuscript.

Funding: This publication was prepared based on results obtained under Subvention of the Division of Biogenic Raw Materials in the Mineral and Energy Economy Research Institute, Polish Academy of Sciences and project LEX4BIO which has received funding from the European Union's Horizon 2020 research and innovation programme under grant agreement no. 818309 (www.lex4bio.eu).

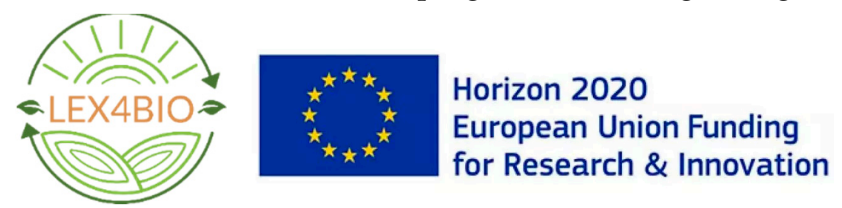

Institutional Review Board Statement: Not applicable.

Informed Consent Statement: Not applicable.

Data Availability Statement: The datasets generated during and/or analysed during the current study are available from the corresponding author on reasonable request.

Conflicts of Interest: Author declares no conflict of interest. 


\section{References}

1. Aldaco, R.; Hoehn, D.; Laso, J.; Margallo, M.; Ruiz-Salmón, J.; Cristobal, J.; Kahhat, R.; Villanueva-Rey, P. Food waste management during the COVID-19 outbreak: A holistic climate, economic and nutritional approach. Sci. Total Environ. 2020, 742, 140524. [CrossRef]

2. Benke, K.; Tomkins, B. Future food-production systems: Vertical farming and controlled-environment agriculture. Sustain. Sci. Pract. Policy 2017, 13, 13-26. [CrossRef]

3. Coccia, M. Why do nations produce science advances and new technology? Technol. Soc. 2019, 59, 101124. [CrossRef]

4. World Population Review. 2021 World Population by Country. 2021. Available online: https://worldpopulationreview.com/ (accessed on 14 April 2021).

5. Pahl-Wostl, C. Governance of the water-energy-food security nexus: A multi-level coordination challenge. Environ. Sci. Policy 2019, 92, 356-367. [CrossRef]

6. Abin, S.; Nangia, A.; Prasad, M.N. Advances in agrochemical remediation using nanoparticles. In Agrochemicals Detection, Treatment and Remediation-Pesticides and Chemical Fertilizers; Prasad, M.N.V., Ed.; Elsevier: Amsterdam, The Netherlands, 2020; pp. 465-485.

7. European Commission. Eurostat. 2021. Available online: https://ec.europa.eu/eurostat (accessed on 14 April 2021).

8. Amann, A.; Zoboli, O.; Krampe, J.; Rechberger, H.; Zessner, M.; Egle, L. Environmental impacts of phosphorus recovery from municipal wastewater. Resour. Conserv. Recycl. 2018, 130, 127-139. [CrossRef]

9. European Commission. Consultative Communication on the Sustainable Use of Phosphorus (COM no. 517, 2013); European Commission: Brussels, Belgium, 2013.

10. Gorazda, K.; Tarko, B.; Wzorek, Z.; Kominko, H.; Nowak, A.K.; Kulczycka, J.; Henclik, A.; Smol, M. Fertilisers production from ashes after sewage sludge combustion-A strategy towards sustainable development. Environ. Res. 2017, 154, 171-180. [CrossRef]

11. Klein, N.; Ramos, T.B.; Deutz, P. Advancing the circular economy in public sector organisations: Employees' perspectives on practices. Circ. Econ. Sustain. 2021. [CrossRef]

12. European Commission. Communication from the Commission to the European Parliament, the Council, the European Economic and Social Committee and the Committee of the Regions: Towards a Circular Economy: A Zero Waste Programme for Europe (COM no. 398, 2014); European Commission: Brussels, Belgium, 2014.

13. Havukainen, J.; Nguyen, M.T.; Hermann, L.; Horttanainen, M.; Mikkilä, M.; Deviatkin, I.; Linnanen, L. Potential of phosphorus recovery from sewage sludge and manure ash by thermochemical treatment. Waste Manag. 2016, 49, 221-229. [CrossRef] [PubMed]

14. Korhonen, J.; Honkasalo, A.; Seppälä, J. Circular economy: The concept and its limitations. Ecol. Econ. 2018, 143, 37-46. [CrossRef]

15. Smol, M.; Marcinek, P.; Duda, J.; Szołdrowska, D. Importance of sustainable mineral resource management in implementing the circular economy (CE) model and the european green deal strategy. Resources 2020, 9, 55. [CrossRef]

16. European Union. European Union general data protection regulation. Off. J. Eur. Union 2016, L'119/1. [CrossRef]

17. European Commission. Communication from the Commission: On the Review of the List of Critical Raw Materials for the EU and the Implementation of the Raw Materials Initiative (COM No. 297, 2014); European Commission: Brussels, Belgium, 2014.

18. European Commission. Communication from the Commission to the European Parliament, the Council, the European Economic and Social Committee and the Committee of the Regions on the 2017 List of Critical Raw Materials for the EU (COM No. 490, 2017); European Commission: Brussels, Belgium, 2017.

19. European Commission. Communication from the Commission to the European Parliament, the Council, the European Economic and Social Committee and the Committee of the Regions: Critical Raw Materials Resilience: Charting a Path towards Greater Security and Sustainability (COM No. 474, 2020); European Commission: Brussels, Belgium, 2020.

20. Arendt, R.; Muhl, M.; Bach, V.; Finkbeiner, M. Criticality assessment of abiotic resource use for Europe-Application of the SCARCE method. Resour. Policy 2020, 67, 101650. [CrossRef]

21. Ten Hoeve, M.; Bruun, S.; Naroznova, I.; Lemming, C.; Magid, J.; Jensen, L.S.; Scheutz, C. Life cycle inventory modeling of phosphorus substitution, losses and crop uptake after land application of organic waste products. Int. J. Life Cycle Assess. 2018, 23, 1950-1965. [CrossRef]

22. Herzel, H.; Krüger, O.; Hermann, L.; Adam, C. Sewage sludge ash-A promising secondary phosphorus source for fertilizer production. Sci. Total Environ. 2016, 542, 1136-1143. [CrossRef]

23. Smol, M. The importance of sustainable phosphorus management in the circular economy (CE) model: The Polish case study. J. Mater. Cycles Waste Manag. 2019, 21, 227-238. [CrossRef]

24. European Commission. Communication from the Commission to the European Parliament, the Council, the European Economic and Social Committee and the Committee of the Regions: Closing the Loop-An EU Action Plan for the Circular Economy (COM No. 614, 2015); European Commission: Brussels, Belgium, 2015.

25. Dróżdż, D.; Wystalska, K.; Malińska, K.; Grosser, A.; Grobelak, A.; Kacprzak, M. Management of poultry manure in PolandCurrent state and future perspectives. J. Environ. Manag. 2020, 264. [CrossRef]

26. European Commission. Proposal for a Regulation on the Making Available on the Market of CE Marked Fertilising Products and Amending Regulations (EC) No 1069/2009 and (EC) No 1107/2009 Annexes 1 to 5 (COM No. 157, 2016); European Commission: Brussels, Belgium, 2016. 
27. Chojnacka, K.; Skrzypczak, D.; Mikula, K.; Witek-Krowiak, A.; Izydorczyk, G.; Kuligowski, K.; Bandrów, P.; Kułażyński, M. Progress in sustainable technologies of leather wastes valorization as solutions for the circular economy. J. Clean. Prod. 2021, 313. [CrossRef]

28. European Commission. Regulation (EU) 2019/1009 Fertilizer Products; European Commission: Brussels, Belgium, 2019.

29. Barquet, K.; Järnberg, L.; Rosemarin, A.; Macura, B. Identifying barriers and opportunities for a circular phosphorus economy in the Baltic Sea region. Water Res. 2020, 171, 115433. [CrossRef] [PubMed]

30. Siciliano, A.; Limonti, C.; Curcio, G.M.; Molinari, R. Advances in struvite precipitation technologies for nutrients removal and recovery from aqueous waste and wastewater. Sustainability 2020, 12, 7538. [CrossRef]

31. Shi, W.; Healy, M.G.; Ashekuzzaman, S.M.; Daly, K.; Leahy, J.J.; Fenton, O. Dairy processing sludge and co-products: A review of present and future re-use pathways in agriculture. J. Clean. Prod. 2021, 314, 128035. [CrossRef]

32. Beesigamukama, D.; Mochoge, B.; Korir, N.K.; Fiaboe, K.K.M.; Nakimbugwe, D.; Khamis, F.M.; Dubois, T.; Subramanian, S.; Wangu, M.M.; Ekesi, S.; et al. Biochar and gypsum amendment of agro-industrial waste for enhanced black soldier fly larval biomass and quality frass fertilizer. PLoS ONE 2020, 15, 1-25. [CrossRef] [PubMed]

33. Cai, A.; Xu, M.; Wang, B.; Zhang, W.; Liang, G.; Hou, E.; Luo, Y. Manure acts as a better fertilizer for increasing crop yields than synthetic fertilizer does by improving soil fertility. Soil Tillage Res. 2019, 189, 168-175. [CrossRef]

34. Smol, M.; Adam, C.; Krüger, O. Use of nutrients from wastewater for the fertilizer industry-Approaches towards the implementation of the circular economy (CE). Desalin. Water Treat. 2020, 186, 1-9. [CrossRef]

35. Zhang, T.; Hou, Y.; Meng, T.; Ma, Y.F.; Tan, M.X.; Zhang, F.S.; Oenema, O. Replacing synthetic fertilizer by manure requires adjusted technology and incentives: A farm survey across China. Resour. Conserv. Recycl. 2021, 168, 105301. [CrossRef]

36. Ye, L.; Camps-Arbestain, M.; Shen, Q.; Lehmann, J.; Singh, B.; Sabir, M. Biochar effects on crop yields with and without fertilizer: A meta-analysis of field studies using separate controls. Soil Use Manag. 2020, 36, 2-18. [CrossRef]

37. European Union. Directive 2008/122/EC of the European Parliament and of the Council. Off. J. Eur. Union 2020, L'312/3. [CrossRef]

38. European Commission. Communication from the Commission: The European Green Deal (COM no. 640, 2019); European Commission: Brussels, Belgium, 2019.

39. Johnson, C.; Sierra, A.R.; Dettmer, J.; Sidiropoulou, K.; Zicmane, E.; Puzzolo, V.; Mengal, P.; Canalis, A.; Paiano, P. The bio-based industries joint undertaking as a catalyst for a green transition in Europe under the European Green Deal. EFB Bioecon. J. 2021, 1, 100014. [CrossRef]

40. Tsai, W.T. Turning food waste into value-added resources: Current status and regulatory promotion in Taiwan. Resources 2020, 9 , 53. [CrossRef]

41. European Commission. Communication from Commission: A Farm to Fork Strategy for a Fair, Healthy and Environmentally-Friendly Food System (COM no. 381, 2020); European Commission: Brussels, Belgium, 2020.

42. Stammes, I.; Maassen, T.; Miller-Kerins, F.; Votano, G.; Palma-Munguia, D.; Yuan, Z.; Gereadts, M. Input on the Proposed Considerations for the EU's "Integrated Nutrient Management Action Plan" (INMAP); VU University Amsterdam: Amsterdam, The Netherlands, 2020; pp. 1-9.

43. Guth, M.; Smędzik-Ambroży, K.; Czyżewski, B.; Stępień, S. The economic sustainability of farms under common agricultural policy in the European Union countries. Agriculture 2020, 10, 34. [CrossRef]

44. Bolfe, É.L.; Jorge, L.A.D.C.; Sanches, I.D.A.; Luchiari Júnior, A.; Costa, C.C.; Victoria, D.D.C.; Inamasu, R.Y.; Grego, C.R.; Ferreira, V.R.; Ramirez, A.R. Precision and digital agriculture: Adoption of technologies and perception of Brazilian farmers. Agriculture 2020, 10, 653. [CrossRef]

45. European Commission. How the Future CAP Will Contribute to the EU Green Deal; European Commission: Brussels, Belgium, 2020.

46. European Commission. Communication from the Commission to the European Parliament, the Council, the European Economic and Social Committee and the Committee of the Regions: Circular Economy Action Plan for a Cleaner and More Competitive Europe (COM no. 98); European Commission: Brussels, Belgium, 2020.

47. Piwowar, A. Consumption of mineral fertilizers in the Polish agriculture-Trends and directions of changes. Agric. Res. 2021. [CrossRef]

48. Ministry of Agriculture and Rural Development. Act of 10 July 2007 on fertilizers and fertilization (items 796 and 1069). J. Laws 2020.

49. Ministry of Agriculture and Rural Development. Regulation of the Minister of Agriculture and Rural Development of 18 June 2008 regarding the implementation of certain provisions of the Act on fertilizers and fertilization (no. 119 item 765). J. Laws 2008.

50. Council of Ministers. Resolution no. 88 of the Council of Ministers of 1 July 2016 on the National Waste Management Plan; Council of Ministers: Warsaw, Poland; p. 2016.

51. Ministry of Environment. Strategy for Treatment of Municipal Sewage Sludge in 2019-2022; Ministry of Environment: Warsaw, Poland, 2018; Volume 51.

52. Smol, M.; Adam, C.; Kugler, S.A. Thermochemical treatment of Sewage Sludge Ash (SSA)-potential and perspective in Poland. Energies 2020, 13, 5461. [CrossRef]

53. Council of Ministers. Roadmap Transformation towards a Circular Economy; Council of Ministers: Warsaw, Poland, 2019.

54. Marcinek, P.; Smol, M. Bioeconomy as one of the key areas of implementing a circular economy (CE) in Poland. Environ. Res. Eng. Manag. 2020, 76, 20-31. [CrossRef] 
55. Jack, J.; Huggins, T.M.; Huang, Y.; Fang, Y.; Ren, Z.J. Production of magnetic biochar from waste-derived fungal biomass for phosphorus removal and recovery. J. Clean. Prod. 2019, 224, 100-106. [CrossRef]

56. Hopke, P.K.; Dai, Q.; Li, L.; Feng, Y. Global review of recent source apportionments for airborne particulate matter. Sci. Total Environ. 2020, 740, 140091. [CrossRef] [PubMed]

57. Chew, K.W.; Chia, S.R.; Yen, H.W.; Nomanbhay, S.; Ho, Y.C.; Show, P.L. Transformation of biomass waste into sustainable organic fertilizers. Sustainability 2019, 11, 2266. [CrossRef]

58. Ministry of Economic Development Labour and Technology. Polish Industrial Policy—Statement; Ministry of Economic Development, Labour and Technology: Warsaw, Poland, 2021.

59. Chief Inspectorate of Plant Health and Seed Inspection. Area of Eligible Nursery Crops in 2019 by Type of Nursery Material and Number of Producers; Chief Inspectorate of Plant Health and Seed Inspection: Warsaw, Poland, 2020.

60. Lupton, S. Markets for waste and waste-derived fertilizers. An empirical survey. J. Rural Stud. 2017, 55, 83-99. [CrossRef]

61. Knez, M.; Jereb, B.; Jadraque Gago, E.; Rosak-Szyrocka, J.; Obrecht, M. Features influencing policy recommendations for the promotion of zero-emission vehicles in Slovenia, Spain, and Poland. Clean Technol. Environ. Policy 2020. [CrossRef]

62. Menges, R.; Cloos, J.; Greiff, M.; Wehrle, J.; Goldmann, D.; Rabe, L. Recycling behavior of private households: An empirical investigation of individual preferences in a club good experiment. Clean Technol. Environ. Policy 2020. [CrossRef]

63. Piwowar, A. Attitudes and opinions of farmers in the context of environmental protection in rural areas in Poland. Environ. Monit. Assess. 2020, 192. [CrossRef] [PubMed]

64. Hou, Y.; Velthof, G.L.; Case, S.D.C.; Oelofse, M.; Grignani, C.; Balsari, P.; Zavattaro, L.; Gioelli, F.; Bernal, M.P.; Fangueiro, D.; et al. Stakeholder perceptions of manure treatment technologies in Denmark, Italy, The Netherlands and Spain. J. Clean. Prod. 2018, 172, 1620-1630. [CrossRef]

65. Hartley, K.; van Santen, R.; Kirchherr, J. Policies for transitioning towards a circular economy: Expectations from the European Union (EU). Resour. Conserv. Recycl. 2020, 155, 104634. [CrossRef]

66. Wang, Y.; Zhu, Y.; Zhang, S.; Wang, Y. What could promote farmers to replace chemical fertilizers with organic fertilizers? J. Clean. Prod. 2018, 199, 882-890. [CrossRef]

67. Okuma, L.O.; Isiorhovoja, R.A. Farmers' perception and willingness to pay for organic fertilizer in Delta state, Nigeria. J. Agric. Food Environ. 2017, 4, 9-20.

68. Danso, G.K.; Otoo, M.; Ekere, W.; Ddungu, S.; Madurangi, G. Market feasibility of faecal sludge and municipal solid waste-based compost as measured by farmers' willingness-to-pay for product attributes: Evidence from Kampala, Uganda. Resources 2017, 6, 31. [CrossRef]

69. Case, S.D.C.; Oelofse, M.; Hou, Y.; Oenema, O.; Jensen, L.S. Farmer perceptions and use of organic waste products as fertilisers-A survey study of potential benefits and barriers. Agric. Syst. 2017, 151, 84-95. [CrossRef]

70. Jensen, L.S.; Thornton, C.; Forrestal, P.J.; Brandsma, J.; Külvet, A.; Riiko, K.; Kabbe, C. Mini-Paper-End-User Requirements for Recycled and Biobased Fertiliser Products; European Innovation Partnership (EIP-AGRI). Available online: https: / / ec.europa.eu/ eip/agriculture/sites/default/files/fg19_minipaper_6_end_user_requirements_en.pdf (accessed on 30 June 2021).

71. Capocasa, F.; Balducci, F.; Marcellini, M.; Bernardini, D.; Navacchi, O.; Mezzetti, B. Comparing nursery behavior, field plant yield and fruit quality of in vitro and in vivo propagated strawberry mother plants. Plant. Cell. Tissue Organ. Cult. 2019, 136, 65-74. [CrossRef]

72. Food and Agriculture Organization of the United Nations. The Future of Food and Agriculture—Trends and Challenges; Food and Agriculture Organization of the United Nations: Rome, Italy, 2017.

73. Hijbeek, R.; Pronk, A.A.; van Ittersum, M.K.; Verhagen, A.; Ruysschaert, G.; Bijttebier, J.; Zavattaro, L.; Bechini, L.; Schlatter, N.; Ten Berge, H.F.M. Use of organic inputs by arable farmers in six agro-ecological zones across Europe: Drivers and barriers. Agric. Ecosyst. Environ. 2019, 275, 42-53. [CrossRef]

74. Valve, H.; Lazarevic, D.; Humalisto, N. When the circular economy diverges: The co-evolution of biogas business models and material circuits in Finland. Ecol. Econ. 2021, 185, 107025. [CrossRef]

75. Jribi, S.; Ismail, H.B.; Doggui, D.; Debbabi, H. COVID-19 virus outbreak lockdown: What impacts on household food wastage? Environ. Dev. Sustain. 2020, 22, 3939-3955. [CrossRef]

76. Filho, W.L.; Voronova, V.; Kloga, M. COVID-19 and waste production in households: A trend analysis. Sci. Total Environ. 2021, 145997. [CrossRef]

77. Kocatürk-Schumacher, N.P.; Zwart, K.; Bruun, S.; Stoumann Jensen, L.; Sørensen, H.; Brussaard, L. Recovery of nutrients from the liquid fraction of digestate: Use of enriched zeolite and biochar as nitrogen fertilizers. J. Plant Nutr. Soil Sci. 2019, 182, 187-195. [CrossRef]

78. Smol, M. Inventory of wastes generated in Polish sewage sludge incineration plants and their possible circular management directions. Resources 2020, 9, 91. [CrossRef]

79. Adam, C.; Vogel, C.; Wellendorf, S.; Schick, J.; Kratz, S.; Schnug, E. Phosphorus recovery by thermochemical treatment of sewage sludge ash-Results of the European FP6-project SUSAN. In Proceedings of the International Conference on Nutrient Recovery From Wastewater Streams, Vancouver, BC, Canada, 30 April 2009; Ken, A., Mavinic, D., Koch, F., Eds.; IWA Publishing: London, UK; Volume 8, pp. 417-430.

80. Kocatürk-Schumacher, N.P.; Bruun, S.; Zwart, K.; Jensen, L.S. Nutrient recovery from the liquid fraction of digestate by clinoptilolite. CLEAN Soil Air Water 2017, 45, 1-7. [CrossRef] 
81. Chojnacka, K.; Moustakas, K.; Witek-Krowiak, A. Bio-based fertilizers: A practical approach towards circular economy. Bioresour. Technol. 2020, 295, 122223. [CrossRef]

82. Kaszycki, P.; Głodniok, M.; Petryszak, P. Towards a bio-based circular economy in organic waste management and wastewater treatment-The Polish perspective. New Biotechnol. 2021, 61, 80-89. [CrossRef] [PubMed]

83. Werle, S.; Sobek, S. Gasification of sewage sludge within a circular economy perspective: A Polish case study. Environ. Sci. Pollut. Res. 2019, 26, 35422-35432. [CrossRef] 